\title{
Features of Implementation in General Educational Institutions Art Programs
}

\author{
Olefirenko Taras \\ Candidate of Pedagogical Sciences, Associate Professor, \\ Dragomanov National Pedagogical University (Ukraine, Kyiv) \\ Zhao Yuxiang \\ PhD graduate \\ Dragomanov National Pedagogical University (Ukraine, Kyiv)
}

\begin{abstract}
The article substantiates the psychological and pedagogical features of the development of artistic and creative abilities of junior schoolchildren in Fine Arts. The authors write that the development of creative abilities depends on the learning conditions, the organization of the exercise process, the sequence of learned actions, the transition from simpler to more complex tasks, from slow to fast pace of their implementation. The main tasks of artistic and aesthetic development of junior schoolchildren by means of Fine arts today are: the development of personal integrity, spirituality and consistent formation of aesthetic culture; education of an active attitude to the aesthetic phenomena of reality and art; systematized the formation of skills of aesthetic perception and evaluation activities, stimulation and actualization of creative potential and improvement of practical knowledge, skills and abilities in the field of Fine arts; described the development of the desire for creative self-realization in various types of poly artistic activities.
\end{abstract}

Key words: primary school, junior schoolchildren, art activity, artistic and creative abilities.

Актуальність дослідження. Відповідно до Типової освітньої програми для закладів загальної середньої освіти під керівництвом О. Савченко, початкова освіта передбачає поділ на два цикли 1-2 класи, що враховують вікові особливості розвитку та потреби дітей i дають можливості забезпечити подолання розбіжностей у ї досягненнях, зумовлених рівнем підготовленості до здобуття освіти [11].

Типову освітню програму для учнів 1-2 класів Нової української школи (НУШ) створено відповідно до Закону України «Про освіту» та Державного стандарту початкової освіти. У програмі окреслено вимоги до конкретних очікуваних результатів навчання; коротко охарактеризовано зміст кожного навчального предмета чи інтегрованого курсу.

Зміст програми має потенціал для формування у здобувачів освіти таких основних компетентностей:

- Вільне володіння державною мовою. 
- Здатність спілкуватися рідною (у разі відмінності від державної) та іноземними мовами.

- Математична компетентність.

- Компетентності у галузі природничих наук, техніки і технологій.

- Інноваційність.

- Екологічна компетентність.

- Інформаційно-комунікаційна компетентність.

- Навчання упродовж життя.

- Громадянські та соціальні компетентності.

- Культурна компетентність.

- Підприємливість та фінансова грамотність [11].

Виклад основного матеріалу. Враховуючи інтегрований характер компетентності, у ході виконання Типової освітньої програми учителям загальноосвітніх закладів рекомендовано використовувати у навчально-виховному процесі з молодшими школярами внутрішньопредметні та міжпредметні зв'язки, що сприяють всеохопленості й об'єктивності результатів початкової освіти й успішності перенесення учнями отриманих знань, умінь і навичок у новій ситуації $[12 ; 17 ; 19 ; 20$; $21]$.

Відповідно до Пояснювальної записки до Типової освітньої програми, що стосується мистецької освітньої галузі, метою навчання мистецтвва у школі $\epsilon$ всебічний i гармонійний художньо-естетичний розвиток особистості дитини, опанування нею здобутків культури у процесі пізнання творів мистецтва; плекання пошани до вітчизняної та зарубіжної мистецької спадщини; формування основних, мистецьких предметних та міжпредметних компетентностей, необхідних учневі загальноосвітньої початкової школи для художньо-творчого самовираження в особистому та суспільному житті.

Досягнення цієї мети відбувається за такими змістовими лініями: «художньотворча діяльність», «сприймання та інтерпретація творів мистецтва», «комунікація засобами мистецтва», що окреслюють одну з моделей осягнення загальних цілей освітньої галузі та розкривають основну місію загальної мистецької освіти.

На розвитку креативності й мистецьких здібностей молодших школярів завдяки 
практичному опануванню ними основ художньої мови різних видів мистецтва та способів художньо-творчого самовираження зосереджена змістова лінія «Художньотворча діяльність». У навчально-виховному процесі початкової школи вона втілюється як наслідок формування в учнів навичок і вмінь застосовувати різноманітні засоби відображення і вираження для створення художніх образів, імпровізування й естетичного перетворення довкілля.

Змістова лінія «Сприймання та інтерпретащія творів мистецтва» спрямована на пізнання різних явищ і подій, що відображені у творах мистецтва. Ії втілення у навчально-виховний процес початкової школи передбачає розвиток емоційно-вольової сфери учнів, збагачення естетичного досвіду, формування в них умінь сприймати, аналізувати, інтерпретувати й оцінювати твори мистецтва, виявляючи (проявляючи) до них емоційне та критичне ставлення.

Впровадження у процес навчання та виховання учнів початкової школи змістової лінії «Комунікація засобами мистецтвва» зорієнтована на їх соціалізацію засобами творів мистецтва, усвідомлення ними свого «Я» (власних мистецьких досягнень i можливостей). Ця лінія передбачає формування в учнів умінь репрезентувати себе й власні досягнення, критично їх оцінювати, взаємодіяти з іншими засобами мистецтва у середовищі, зокрема у ході різних культурно-мистецьких заходів, обговорень тощо, а також формування у них уявлень про можливості й способи регулювання свого емоційного стану завдяки творам і засобам мистецтва.

Опанування учнями творів та засобів мистецтва у початковій школі грунтується на основах компетентнісного, особистісно зорієнтованого, діяльнісного, ігрового й інтегративного підходів.

Мистецтво сприяе формуванню в учнів початкової школи основних компетентностей, зокрема, у процесі:

- усного висловлювання своїх вражень від споглядання творів мистецтва; за допомогою коментування дорослого й оцінювання власної художньо-творчої діяльності (вільне володіння державною мовою/ здатність спілкуватися рідною).

- здійснення елементарних розрахунків (наприклад, для встановлення пропорцій, визначення метражу, заповненості ритму кольорових акцентів тощо) (математична компетентність). 
- спостереження, дослідження та відтворення довкілля i явищ природи засобами мистецтва (компетентності у галузі природничих наук, техніки і технологій, екологічна компетентність);

- самостійного (чи за допомогою дорослого) застосування інформаційних технологій для отримання мистецької інформації, художнього творення (інформаційнокомунікаційна компетентність);

- формування уміння визначати власні художні інтереси, досягнення i потреби; прагнення доцільно використовувати свій час для пізнання, сприймання, творення мистецтва (навчання упродовж життя);

- співпраці з іншими, зокрема участі у мистецьких заходах, прикрашанні середовища для друзів, сусідів; прояву відповідальності за особистий чи колективний результат; застосування творів мистецтва для отримання задоволення (вплив на власний емоційний стан та оточення) (громадянські й сочіальні компетентності, пов'язані з ідеями демократії, справедливості, добробуту $і$ здорового способу життя, з усвідомленням рівних прав і можливостей);

- опанування народних традицій і творів мистецтва рідного краю; формування толерантного ставлення до мистецтва різних народів (культурна компетентність);

- проявів творчої ініціативності й намагання їі втілити, зокрема у практичній художньо-творчій діяльності (індивідуальній та колективній); презентації результатів власних мистецьких досягнень (підприємливість та фінансова грамотність);

- виявлення бажання впровадити нові ідеї (інноваціийність).

Мистецька освітня галузь може втілюватися в інтегрованих курсах або предметах для вивчення за окремими видами мистецтва: наприклад, музичне мистецтво, образотворче мистецтво тощо, за умови досягнення учнями впродовж циклу навчання усіх очікуваних результатів у цій галузі.

Для аналізу наявності й застосування колективного способу навчання згідно 3 програмою НУШ у галузі «Мистецтво», ми обрали підручники «Мистецтво: підручник інтегрованого курсу для 1 класів закладів загальної середньої освіти» авторів О. Калініченко [2], Л. Масол [9], Т. Рублі [13], Л. Кондратової [4].

Найбільша кількість творчих завдань із застосуванням колективного способу навчання міститься у підручнику «Мистецтва» О. Калініченко [2]. 
На перших сторінках підручника серед умовних позначок є така, що має назву «Творимо разом». Ця умовна позначка в підручнику [2] вказує на завдання для виконання учнями колективної творчої діяльності у класі. Вперше у підручнику позначка «Творимо разом» міститься [2, с. 17], тема 4 «Милуємося довкіллям» із колективним завданням прикрасити куточок шкільного подвір'я орнаментом із природних матеріалів: листя, плодів, шишок, камінців.

В темі 5 «Щедра осінь» [2, с. 21] діти мають індивідуальне завдання: виліпити 3 пластиліну овочі та фрукти - дари осені, а потім за умовною позначкою «Творимо разом» мусять виконати колективне завдання: виліплені овочі та фрукти красиво скласти на тарілці чи картоні.

Тема 8 «Мої захоплення» [2, с. 33] містить не менш цікаве й захоплююче завдання для молодших школярів. Спочатку вони мусять на картоні виконати із пластиліну зображення рибок, а потім за інструкцією позначки «Творимо разом» учні об’єднуються у пари для створення акваріумів та репрезентують свою спільну роботу.

Заклик до виконання колективної роботи міститься й на сторінках теми 14 «Зимові свята» [2, с.57], де молодшим школярам пропонують прикрасити клас новорічними витинанками.

Під час вивчення теми 19 «Світ рослин у мистецтві» $є$ умовна позначка «Творимо разом» [2, с. 79], відповідно до якої учні мусять виконати колективну роботу й створити декоративну композицію «Квіткова галявина».

Тема 25 «Герої дитячих книжок» [2, с. 102] містить також надзвичайно креативне та цікаве, на нашу думку, завдання для колективної творчої співпраці учнів. За умовною позначкою «Творимо разом» вони мусять спочатку пригадати героїв 3 казок, обговорити між собою, до яких казок вони будуть малювати ілюстрації, а потім скласти малюнки до казки в одну книжку [2].

На нашу думку, підручник «Мистецтво» О. Калініченко є одним з кращих для учнів 1-го класу, оскільки містить дуже багато нестандартних підходів до здійснення творчих завдань, одним з яких $є$ саме колективний спосіб виконання учнями мистецьких робіт. 
Опрацювавши підручник «Мистецтво» [9], за авторством Л. Масол, маємо підстави твердити, що колективних завдань для учнів на уроках образотворчого мистецтва дуже мало.

Колективна робота міститься на сторінках підручника [9, с. 52, 55, 129], де учні отримують завдання створити разом із друзями прикрасу зі сніжинок у певному ритмі, створити разом із друзями композицію «Танок сніговиків». Колективним завданням для молодших школярів є створення виставки-ярмарку з найкращих творчих робіт учнів (український сувенір для друга чи подружки з європейської країни). У ході виконання цього завдання прекрасно втілюється формування в учнів початкової школи компетенції підприємливості й фінансової грамотності. Як засвідчує практика, сучасні діти дуже полюбляють такі завдання.

Детально проаналізувавши підручник «Мистецтво», який створив очолюваний Т. Рублею авторський колектив [13], ми знайшли досить цікаві завдання для колективного способу навчання образотворчого мистецтва учнів початкової школи, так у темі «На лісовій галявині» [13, с. 23], є завдання для виконання в групах, а саме: об’єднатися з друзями в групи, виліпити із пластиліну грибочки і яблучка й скласти їх у спільний кошик. Наприкінці цього завдання є питання до дітей: «Чи сподобалося Вам працювати колективно? Поясніть свою думку». На наш погляд, думка учнів справді є важливою ноткою, яка мусить пролунати наприкінці кожного уроку для того, щоб з'ясувати переваги та недоліки виконання учнями мистецької роботи як індивідуально, так і в колективі (групі, парі).

Особливо хочеться звернути увагу на те, як гармонійно обраний в цьому підручнику музичний супровід для виконання кожного завдання. Маємо підстави твердити, що завдяки низці гармонійно підібраних для цього підручника музичних творів (К. Дебюссі, Е. Гріг, Р. Шуман, К. Сен-Санс, П. Чайковський, А. Вівальді та ін.) музика, без сумніву, інтегрувала в уроки образотворчого мистецтва. На нашу думку, це найкращий підручник з музичним супроводом для уроків мистецтва у початковій школі. Так, при вивченні теми «Краса осіннього листя» [13, с. 31], також є завдання для колективної роботи: у групах учні виконують аплікації з осіннього листя. Прекрасний музичний супровід надихає дітей на творчість. 
Завдання для колективної образотворчості молодших школярів міститься у темі «Парад моїх улюбленців» іграшки [13, с. 42], у темі «Домашні улюбленці» [13, с. 72], та у темі «Театральна подорож» [13, с. 92]. Для їх виконання діти також мусять об’еднатися з друзями в групи.

Автори підручника [13] дуже чуйно поставилися до організації образотворчої діяльності учнів у групах, а тому при формуванні кожного колективного завдання наголошують на тому, що, працюючи у групі, доцільно звертати увагу на творчу роботу друзів, можливо, їм необхідна допомога чи підтримка.

Підручник «Мистецтво», який створив очолюваний Л. Кондратовою колектив авторів, також містить завдання для колективної роботи в групах, однак вони мають відношення лише до музичного й театрального мистецтва, а завдань для колективної образотворчості молодших школярів у ньому немає.

Висновки. Проаналізувавши грунтовно згадані вище підручники з мистецтва, ми дійшли висновку про те, що поняття «колективна робота» $\mathrm{i}$ «колективна творча діяльність» застосовуються у них досить рідко, але майже всі вони містять завдання для колективного способу навчання молодших школярів на уроках образотворчого мистецтва, що $є$ надзвичайно важливим та дієвим засобом їх навчання в умовах реформування Нової української школи.

\section{References}

1. Interaktyvni metody navchannia [Interactive teaching methods]: Navch. Posibnyk. Shchetsin : Vyd-vo WSAP, 2005. 170 p. URI : http://shkola.ostriv.in.ua/publication/code12a81b67900c2.

2. Kalinichenko O. V. Mystetstvo [Art]: pidruch. intehrovanoho kursu dlia $1 \mathrm{kl}$. zakladiv zahalnoi serednoi osvity. K.: Vydavnychyi dim «Osviti», 2018.

3. Kelm S. V. Netradytsiini uroky obrazotvorchoho mystetstva [Unconventional lessons of fine arts]. Cherkasy : ChOIPOPP, 2014.

4. Kondratova L. H. Mystetstvo [Art]: pidruch. intehrovanoho kursu dlia $1 \mathrm{kl}$. zakladiv zahalnoi serednoi osvity. Ternopil: Navchalna knyha - Bohdan, 2018.

5. Kolektyvnyi sposib navchannia [Collective way of learning]. URI : https://uk.wikipedia.org/wiki/Колективний_спосіб_навчання

6. Kollektivnyj sposob obucheniya na urokah IZO [A collective way of teaching in art lessons]. Sajt dlya uchitelej «Multiurok». URI : https://multiurok.ru/files/kolliektivnyisposob-obuchieniia-na-urokakh-izo.html 
7. Kolodnytska O. Proektni tekhnolohii u konteksti zahalnopedahohichnoi pidhotovky vchyteliv [Design technologies in the context of educational pedagogical training of readers]. Problemy pidhotovky suchasnoho vchytelia. 2011. № 4 (Ch.2).

8. Kuznetsov A. M. Kolektyvni zaniattia v dynamichnykh hrupakh [Collective lessons in dynamic groups]. Maister-klas. URI : http://uk-ua.vedavrat.org/Jyotish/11598/collective-learning-methodколективний-спосіб-навчання-ксв

9. Masol L. M. Mystetstvo [Art]: pidruch. intehr. kursu dlia 1 kl. zakl. zah. sered. Osvity. Kyiv : Heneza, 2018.

10. Metodyka i tekhnolohyia [Methodology and technology]. Sait Osvita.ua. URI : http://ru.osvita.ua/school/method/technol/6630/

11. Opublikuvaly typovi osvitni prohramy dlia 1-2 klasiv NUSh [Published standard educational programs for 1-2 classes of NUS]. URI : http://nus.org.ua/news/opublikuvalytypovi-osvitni-programy-dlya-1-2-klasiv-nush-dokumenty

12. Pet'ko L. V. Formuvannya profesiyno orientovanogo inshomovnogo navchalnogo seredovishcha $v$ umovah universitetu dlya studentiv spetsialnosti «Muzichne mistetstvo» (na prikladi virsha Meri Hovitt «Pavuk i Muha») [Formation of professionally oriented foreign language teaching environment in the terms of university for students of Music Art specialty (on illustration of a poem «The Spider and the Fly» by Mary Howitt)]. Naukovi zapiski Berdyanskogo derzhavnogo pedagogichnogo universitetu. Pedagogichni nauki: zb. nauk. pr. Issue 1. Berdyansk : FO-P Tkachuk O.V., 2016. Pp. 184-190.

13. Rublia T. Ye. Mystetstvo [Art]: pidruch. intehr. kursu dlia 1 kl. zakl. zah. sered. osvity. Kharkiv: Vyd-vo «Ranok», 2018.

14. Typolohiia suchasnykh pedahohichnykh tekhnolohii [Typology of modern pedagogical technologies]. URI : http://obdarovanist.at.ua/MetodSkrunka/seminarske_zanjattja_tipologija_suchasnikh_p edagog.pdf

15. Uroky obrazotvorchoho mystetstva [Fine art lessons]: posibnyk dlia vchytelia: 4 kl. Ternopil : Navch. knyha "Bohdan”, 2015.

16. Chaikovskyi P. I. Muzychnyi fails "Vals kvitiv" [Music file "Waltz of Flowers"]. URI : https://youtube/9a4DnEWXMHM

17. Didur N., Matviienko O. The modern condition of forming sociocultural competence in future elementary school teachers. Intellectual Archive. Toronto : Shiny Word. Corp. (Canada), 2017. Vol. 6. No. 6. Pp. 103-112.

18. Klimt Tree of life from Kuwait. URI : https://artprojectsforkids.org/klimt-tree-lifekuwait/

19. Matviienko O. Pedagogy of partnership in the process of setting new Ukrainian school // Challenges and opportunities of scientific thought development : collection of scientific articles. - GPG Publishing Group, Pretoria, South Africa, 2017. Pp. 151-156.

20. Matviienko O., Scyhmeystryh O. Multicultural upbringing of primary school children in the conditions of Ukraine's eurointegration // World scientific extent : Collection of 
scientific articles. - Agenda Publishing House, Coventry, United Kingdom, 2017. Pp. 410-415.

21. Pet'ko L. V. Formation of professionally oriented foreign language teaching environment in the conditions of university for students of specialties 023 «Fine Arts» and 022 «Design»// Economics, management, law:realities and perspectives: Collection of scientific articles. Psychology. Pedagogy and Education. - Les Editions L'Originale, Paris, France. 2016. Pp. 466-470.

22. Reflactions for 2011-2012. URI : http://kids-

finelines.blogspot.com/2011/09/reflections-for-2011-12.html?m=1

\section{Translation of the Title, Abstract and References to the Author's Language}

УДК 373.5.016:7-021.321

Олефіренко Тарас, Юйсян Чжао. Особливості впровадження у загальноосвітніх закладах освітньої програми «Мистецтво».

У статті представлено особливості розвитку художньо-творчих здібностей молодших школярів в образотворчій діяльності. Розвиток творчих здібностей залежить і від умов навчання, організації процесу вправляння - послідовності засвоюваних дій, переходу від простіших до складніших завдань, від повільного до швидкого темпу їх виконання. Основними завданнями художньо-естетичного розвитку молодших школярів засобами образотворчого мистецтва сьогодні $є$ : розвиток особистісної цілісності, духовності та послідовне формування естетичної культури; виховання активного ставлення до естетичних явищ дійсності та мистецтва; цілеспрямоване і систематизоване формування навичок естетичного сприймання та оцінної діяльності; стимулювання та актуалізація творчого потенціалу й удосконалення практичних знань, навичок та умінь в галузі образотворчого мистецтва; розвиток прагнення до творчої самореалізації в різних видах поліхудожньої діяльності.

Ключові слова: початкова школа, учні молодшого шкільного віку, образотворча діяльність, художньо-творчі здібності.

\section{Лimepamypa}

1. Інтерактивні методи навчання: навч. посібник. Щецин : Вид-во WSAP, 2005. 170 с. URI : http://shkola.ostriv.in.ua/publication/code-12a81b67900c2.

2. Калініченко О. В. Мистецтво: підруч. інтегрованого курсу для 1 кл. закладів загальної середньої освіти. Київ : Видавничий дім «Освіта», 2018. 128 с.

3. Кельм С. В. Нетрадиційні уроки образотворчого мистецтва. Черкаси : ЧОІПОПП, 2014. $56 \mathrm{c}$.

4. Кондратова Л. Г. Мистецтво: підруч. інтегрованого курсу для 1 кл. закладів загальної середньої освіти. Тернопіль : Навчальна книга «Богдан». 2018. 144 с.

5. Колективний спосіб навчання. URI : https://uk.wikipedia.org/wiki/Колективний_спосіб_навчання.

6. Коллективный способ обучения на уроках ИЗО. Сайт для учителей «Мультиурок». URI : https://multiurok.ru/files/kolliektivnyi-sposob-obuchieniia-na-urokakhizo.html. 
7. Колодницька О. Проектні технології у контектсті загальнопедагогічної підготовки вчителів. Проблеми підготовки сучасного вчителя. 2011. № 4 (Ч. 2). С. 69.

8. Кузнецов А. М. Колективні заняття в динамічних групах. Майстер-клас. URI : http://uk-ua.vedavrat.org/Jyotish/11598/collective-learning-method-колективний-спосібнавчання-ксв.

9. Масол Л. М. Мистецтво: підруч. інтегр. курсу для 1 кл. закл. заг. серед. освіти / Л. М. Масол, О. В. Гайдамака, О. М. Копотило. Київ : Генеза, 2018. 144 с.

10. Методика и технология. Сайт Освіта.uа. URI : http://ru.osvita.ua/school/method/technol/6630/.

11. Опублікували типові освітні програми для $1-2$ класів НУШ. Режим доступу : http://nus.org.ua/news/opublikuvaly-typovi-osvitni-programy-dlya-1-2-klasiv-nushdokumenty.

12. Петько Л. В. Формування професійно орієнтованого іншомовного навчального середовища в умовах університету для студентів спеціальності «Музичне мистецтво» (на прикладі вірша Мері Ховітт «Павук і Муха»). Наукові записки Бердянського державного педагогічного університету. Педагогічні науки: зб. наук. пр. Вип. 1. Бердянськ : ФО-П Ткачук О.В., 2016. С. 184-190.

13. Рубля Т. С. Мистецтво: підруч. інтегр. курсу для 1 кл. закл. заг. серед. Освіти. Харків : Вид-во «Ранок», 2018. 104 с.

14. Типологія сучасних педагогічних техгнологій.

URI : http://obdarovanist.at.ua/MetodSkrunka/seminarske_zanjattja_tipologija_suchasnikh_pedago g.pdf

15. Уроки образотворчого мистецтва: посібник для вчителя: 4 кл./ С. І. Федун, О. В. Чорний. - Тернопіль: Навч. книга - Богдан, 2015. 112 с.

16. Чайковський П. I. Музичний файл «Вальс квітів». URI : https://youtu.be/9a4DnEWXMHM.

17. Didur N., Matviienko O. The modern condition of forming sociocultural competence in future elementary school teachers. Intellectual Archive. Toronto : Shiny Word. Corp. (Canada), 2017. Vol. 6. No. 6. Pp. 103-112.

18. Klimt Tree of life from Kuwait. URI : https://artprojectsforkids.org/klimt-tree-life-kuwait/

19. Matviienko O. Pedagogy of partnership in the process of setting new Ukrainian school // Challenges and opportunities of scientific thought development : collection of scientific articles. - GPG Publishing Group, Pretoria, South Africa, 2017. Pp. 151-156.

20. Matviienko O., Scyhmeystryh O. Multicultural upbringing of primary school children in the conditions of Ukraine's eurointegration // World scientific extent : Collection of scientific articles. - Agenda Publishing House, Coventry, United Kingdom, 2017. Pp. 410-415.

21. Pet'ko L. V. Formation of professionally oriented foreign language teaching environment in the conditions of university for students of specialties 023 «Fine Arts» and 022 «Design»// Economics, management, law:realities and perspectives: Collection of scientific articles. Psychology. Pedagogy and Education. - Les Editions L'Originale, Paris, France. 2016. Pp. 466-470.

22. Reflactions for 2011-2012. URI : http://kidsfinelines.blogspot.com/2011/09/reflections-for-2011-12.html?m=1 